\title{
Pengertian dan Sejarah Munculnya Laissez Faire serta Kritik Adam Smith Terhadap Merkantilisme
}

\author{
Rezki Amalia Fathurrahman (90100118108) \\ Email:rezkiamalia56@gmail.com
}

\begin{abstract}
Abstrak
Seperti diketahui kita bahwa teori mekanisme pasar secara alami dikembangkan oleh Bapak Ekonomi Adam Smith yaitu seorang pemikir dari Skotlandia, Eropa Barat. Tapi sebelum mengetahui bagaimana bisa muncul mekanisme pasar alami kita lebih harus tahu terlebih dahulu apa itu Laissez. Faire dan bagaimana sejarah munculnya teori Laissez. Faire. Laisez. Faire adalah sebuah istilah yang artinya biarkan semua berjalan secara alami yang kemudian dikembangkan oleh Adam Smith tentang perdagangan bebas. Bagaimana bisa muncul Laissez Faire ini dimulai karena ada kritikan dari pemikir Mazhab Fisiokrat yang bahwa Merkantilisme mengatakan suatu negara akan makmur jika negara tersebut menyimpan uang dalam bentuk logam yaitu, emas dan perak dan sumber pendapatan berasal dari perdagangan luar negeri bisa memonopoli pasar atau menguasai pasar juga indvidu tidak berhak untuk berusaha sendiri tanpa seizing dari pemerintah sehingga fisiokrat menganggap bahwa pemerintah cenderung mengontrol rakyat dan tidak diberi kesempatan untuk mengembangkan usaha yang ingin dijalankan dan sekelompok orang yang bisa memulai usaha atau berdagang. Selain itu fisiokrat juga menuduh bahwa membuat barang-barang dalam negeri menjadi mahal dan menentukan pajak tinggi hingga rakyat maupun pedagang tidak sanggup untuk membeli dan memulai usaha karena tingginya pajak yang ditetapkan. Selain kritik pemikir mazhab fisiokrat, Adam Smith juga mengkritisi tentang Merkantilisme yang mengatakan kesejahteraan suatu negara tidak ditentukan oleh jumlah uang yang disimpan dan diedarkan saja tetapi juga dilihat PDB (Produk Domestik Bruto) pendapatan nasional. Dengan meningkatnya pendapatan nasional dan perdagangan bebas berarti tinggi pula kesejahteraan suatu negara. Untuk meningkatkan kesejahteraan suatu negara maka pemerintah tidak ikut campur dalam terciptanya perdagangan bebas yang bisa menimbulkan persaingan. Untuk bisa bersaing dengan pedagang lain maka diperlukan spesialisasi dan pembagian kerja yang bersifat kemutlakan absout atau memproduksi suatu barang yang volume lebih besar dan lebih unggul tapi input produksi tetap sama. Jadi intinya kesejahteraan negara akan meningkat jika melakukan perdagangan bebas dan melakukan spesialisasi dan pembagian kerja yang lebih efisien dan efektif.
\end{abstract}

Kata Kunci: Laissez Faire, Adam Smith 


\section{Pendahuluan}

Sebelum membahas bagaimana sejarah munculnya Laissez Faire, kita terlebih dahulu bagaimana pengertian dari Laissez Faire. Secara bahasa berasal dari Bahasa Prancis bahwa Laisez artinya biarkan dan Faire artinya semua berjalan atau berjalan apa adanya jadi secara istilah adalah biarkan segala sesuatu berjalan secara alami.(Marx Skousen 2009) Sehingga Adam Smith menggambil prinsip Laissez Faire dengan menggunakan konsep perdagangan bebas dilakukan tanpa adanya intervensi dari pemerintah dan biarkan mekanisme pasar berjalan secara alami.(Ubaid Al Faruq dan Edi Mulyanto 2017)

Jadi bagaimana munculnya Laissez Faire ini dimulai dari pada akhir abad 17 Jean Baptiste Colbert pernah bertanya kepada pengusaha untuk membantu mereka. Dan pengusaha itu menjawab, "Laissez nous Faire" yang artinya biarkan kami melakukan sendiri. Sehingga beberapa penggarang di Prancis pada awal abad 17 termasuk Marquis d'Argenson menggunakan menggunakan prinsip Laissez Faire juga beberapa pemikir lain seperti Turqot menerapakan aturan "Laissez Faire, Laissez Passar" yang artinya biarkan segala sesuatu berjalan dengan sendirinya dan hal-hal yang baik masuk.(Marx Skousen 2009). Sehingga Adam Smith terinspirasi dari istilah Laissez Faire untuk mengembangkan konsep ekonomi perdagangan bebas dan Adam Smith mengkritik konsep Merkantilisme yang mengatakan bahwa sejahtera atau makmurnya suatu negara tidak saja ditentukan oleh jumlah uang yang disimpan dan 
dibelanjakan tetapi ditentukan dengan besarnya pendapatan nasional atau Produk Domestik Bruto yang memiliki sumbangan terbesar terhadap perekonomian dan perdagangan internasional, selain itu untuk meningkatkan pendapatan nasional dan perdagangan luar negeri di perlukan kebijakan yang dimana pemerintah mengurangi intervensi pemerintah sehingga tercipta perdagangan bebas. Dan dengan adanya perdagangan bebas berarti ada persaingan antar negara sehingga mendorong suatu negara untuk melakukan spesialisasi dan pembagian kerja yang efektif dan efisien dengan menggunakan kemutlakan absolut atau keunggulan apa yang dimiliki oleh suatu produk agar bisa bersaing dengan negara lain. Jadi menurut Adam Smith bahwa negara akan makmur jika negara tersebut menerapkan kebijakan perdagangan bebas dan melakukan spesialisasi dan pembagian kerja yang efektif dan efisien.(Abdul Wahab 2013) 


\section{Pembahasan}

Yang pertama di bahas ialah Laissez Faire yang telah dijelaskan sebelumnya berasal dari Bahasa Prancis yang berarti biarkan semua berjalan sendiri secara alami maksudnya biar para individu mengembangkan apa yang diinginkan termasuk dalam hal melakukan perdagangan tanpa ada campur tangan dari pemerintah sehingga menginspirasikan Adam Smith untuk menggunakan prinsip Laissez Faire.(Marx Skousen 2009)

Alasan Adam Smith menggunakan prinsip Laissez Faire adalah bahwa segala sesuatu harus berjalan secara hukum alam sehingga tercipta mekanisme pasar antara permintaan dan penawaran dan pemerintah tidak mengintervensi atau ikut campur dalam perekonomian dan biarkan berjalan alami dan harmonis atau selaras.(Ubaid Al Faruq dan Edi Mulyanto 2017)

Dan konsep mekanisme pasar yang dikembangkan oleh Adam Smith sedikit mirip dengan konsep ekonomi mekanisme pasar dari Al Ghazali yang mengatakan bahwa mekanisme pasar sudah menjadi hukum Alam atau Sunatullah yang mengatakan bahwa manusia memiliki hasrat untuk memenuhi kebutuhan dirinya dan itu atas kehendak sendiri untuk memuaskan diri terhadap kebutuhan ekonomi yang di inginkan.(Sirajuddin 2016)

Bagaimana muncul Laissez Faire ini dimulai dari Mazhab Fisiokrat mulai lahir

di Prancis setelah berakhirnya masa merkantilis tahun 1756. Fisiokrat secara bahasa 
berasal dari bahasa Yunani yaitu Physia berarti alam dan cratos artinya kekuasan. Jadi secara definisi Fisiokrat adalah pemikir yang mengatakan segala sesuatu sumber daya alam adalah kunci banyak sumber kekayaan yang dimiliki. Selain itu Mazhab Fisiokrat ini mengkritik pemikiran merkantilisme ini dan tokoh yang terkenal dengan Mazhab ini adalah Francois Quesnay (1654-1774) seorang dokter sekaligus pemikir ekonomi dari Prancis yang merupakan dokter pribadi Raja Louis XV yang memperkenal buku yang berjudul "Tableau Economique" adalah suatu model matematika yang membahas tentang perekonomian. Quesnay memiliki pendapat ekonomi yang terbagi atas empat sektor yaitu:

1. Sektor petanian yaitu menghasilkan makanan yang bahan mentah dan hasil pertanian lainnya seperti buah, gandum, sayuran dan lain-lain.

2. Sektor Manufaktur atau industri memproduksi barang-barang sudah jadi pakaian dan alat-alat untuk bertani.

3. Sektor Kelas Pemilik tanah tidak menghasilkan ekonomi tetapi biasa disewakan tempatnya untuk melakukan produksi manufaktur atau industri sehingga menghasilkan surplus atau pendapatan yang dihasilkan lalu dibagi dua antara pemilik tanah dan pemilik alat industri maupun pengelola pertanian.(Ubaid Al Faruq dan Edi Mulyanto 2017)

Selain itu Quesnay membagi kelas masyarakat atas empat golongan sebagai berikut.

1. Kelas Masyarakat Produktif seperti petani. 
2. Kelas Tuan Tanah yaitu pemilik tanah.

3. Kelas tidak produktif dan cendrung steril seperti pedagang.

4. Kelas Masyarakat Buruh yang menerima upah dari hasil kerjanya.

Menurut Quesnay bahwa sesungguhnya yang berjasa atas kesejahteraan suatu negara adalah buruh bukan pedagang atau saudagar yang tidak menghasilkan suatu produksi karena para petani berjasa sedangkan para masa merkantilisme justru mereka ditekan dan harus membayar pajak yang sangat tinggi dan punggutan liar. Sehingga petani menentang melawan saudagar karena dianggap mereka diuntungkan dibanding kaum petani. sehingga yang Quesnay kemukakan menjadi kenyataan terjadi Revolusi Prancis pada akhir abab 18. Pemikir Fisiokrat meminta pemerintah untuk tidak mengatur aktivitas ekonomi agar berjalan secara alami dan tidak melakukan monopoli dan memberikan hak istimewa kepada kelompok tertentu saja.(Ubaid Al Faruq dan Edi Mulyanto 2017)

Sehingga muncul kritik Adam Smith atas Merkantilisme yang mengatakan makmurnya suatu negara tidak saja ditentukan oleh jumlah uang dalam bentuk logam seperti emas dan perak saja tetapi ditentukan oleh tinggi pendapatan nasional atau Produk Domestik Bruto yang memiliki sumbangan terbesar terhadap perdagangan internasional, selain itu untuk meningkatkan pendapatan nasional dan perdagangan luar negeri di perlukan kebijakan yang dimana pemerintah mengurangi untuk mengatur perekonomian sehingga tercipta perdagangan bebas. Dan adanya perdagangan bebas berarti ada persaingan sehingga mendorong suatu negara untuk melakukan spesialisasi 
dan pembagian kerja yang efektif dan efisien dengan menggunakan kemutlakan absolut atau keunggulan apa yang dimiliki oleh suatu produk agar bisa bersaing dengan negara lain. Kesejahteraan suatu negara ditentukan jika ia melakukan perdagangan bebas dan spesialisasi dan pembagian kerja agar lebih efisen.(Abdul Wahab 2013) 


\section{Kesimpulan}

Bahwa Laissez Faire adalah suatu pandangan yang mengatakan bahwa biarkan berjalan secara alami dan adanya. Sehingga menginspirasi Adam Smith untuk mengembangkan konsep ekonomi mekanisme pasar yang mengatakan biarkan pasar berjalan secara alami sesuai dengan mekanisme pasar dan konsep ekonomi tentang mekanisme pasar juga di kemukakan oleh Al Ghazali yang mengatakan bahwa mekanisme pasar berjalan secara alami sudah menjadi hukum alam atau Sunatullah. Karena Laissez Faire ini muncul kritik terhadap merkantilisme yang dilakukan oleh fisiokrat. menurut Quesnay mengatakan bahwa sesungguhnya yang berjasa atas kesejahteraan suatu negara adalah petani bukan pedagang karena pedagang hanya tidak menghasilkan produksi barang ataupun pertanian dibandingkan petani. selain kritik dari mazhab fisiokrat, Adam Smith juga mengkritik merkantilisme yang mengatakan bahwa kesejahteraan suatu negara tidak ditentukan oleh banyaknya jumlah uang seperti emas dan perak tetapi ditentukan oleh banyak pendapatan nasional yang disebut dengan Produk Domestik Bruto (PDB). Dan juga melakukan spesialisasi dan pembagian kerja sesuai keahliannya masing-masing agar lebih efisien. 


\section{Daftar Pustaka}

Abdul Wahab. 2013. Ekonomi Internasional. Makassar: Alauddin Unversity Press.

Marx Skousen. 2009. Sang Maestro:Teori-Teori Ekonomi Modern. 3rd ed. Jakarta: Kencana.

Sirajuddin. 2016. “Konsep Pemikiran Ekonomi Al-Ghazali.” Laa Maisyir 3(1):46-60.

Ubaid Al Faruq dan Edi Mulyanto. 2017. Sejarah Teori-Teori Ekonomi. Tangerang Selatan: UNPAM PRESS. 